REVISTA X, Curitiba, volume 14, n.6,p. 203-217 2019.

\title{
LITERATURE AS TIME TRAVEL: ANNOTATED TRANSLATION UNVEILING THE IMPLICIT HYPER-TEXT
}

Literatura como Viagem no Tempo: Tradução Anotada Desvelando o Hipertexto Implícito

\author{
Davi Silva GONÇALVES (UFSC)
}

\begin{abstract}
The purpose of this article is to discuss the choice for footnotes during literary translation, as an endeavour to re-establish a connection between readers and the story through the references that are made - and which, otherwise, would possibly be lost. More specifically, I herein reflect upon the references provided by the characters of Sunshine sketches of a little town (LEACOCK, 1912), which prove to be pivotal for the affectionate characterisation of Mariposa as a construct of a particular cultural-historical setting. The acknowledgment of hyper-textuality as inherent to the literary experience evinces that translation can operate not as to provide the text with a surface of absolute transparency, but, on the contrary, it has to do with giving a literary piece one more layer of mobile meanings. My findings point to the direction of these unavoidable systems of mobile meanings, and translation might give us the tools to become less colour blind towards the specificity of the other who moves. I want my readers to see in Mariposa, this ever-changing but never-dying town where Leacock's (1912) novel is set, other stories emerging, with new characters who are (re)born through their translation recreation.
\end{abstract}

Keywords: Chronotope; Hyper-textuality; Literary translation.

Resumo: O propósito deste artigo é discutir a escolha por notas de rodapé durante a tradução literária, como tentativa de reestabelecer uma conexão entre leitores e a estória através das referências feitas - e que, de outro modo, seriam possivelmente perdidas. Mais especificamente, reflito aqui sobre as referências trazidas pelos personagens de Sunshine sketches of a little town (LEACOCK, 1912), que se mostram cruciais para a caracterização afetuosa de Mariposa como um modelo de um constructo cultural e histórico único. $\mathrm{O}$ reconhecimento da hipertextualidade como inerente à experiência literária mostra como a tradução pode operar de forma não a proporcionar o texto com uma superfície de transparência absoluta, mas sim dando à peça literária mais uma camada de sentidos móveis. Meus resultados apontam para a direção desses inescapáveis sentidos móveis, e a tradução pode nos dar as ferramentas para nos tornarmos mais atentos à especificidade do outro que se move. Quero que meus leitores vejam, em Mariposa, essa cidadezinha sempre em transformação, mas nunca em risco de desaparecer, onde a estória de Leacock (1912) se passa, outras estórias emergindo, com novos personagens que (re)nascem através de sua recriação tradutória.

\footnotetext{
${ }^{1}$ Mestrando em Estudos Linguísticos e Literários pelo Programa de Pós-Graduação em Língua Inglesa da Universidade Federal de Santa Catarina (UFSC). goncalves.davi@ hotmail.com
} 
REVISTA X, Curitiba, volume 14, n.6,p. 203-217 2019.

Palavras-chave: Cronotopo; Hipertextualidade; Tradução literária.

Rimos das contradições entre linguagem $e$ metalinguagem com que o texto lida, exibindo a própria falência, ou do fato de que no equívoco do texto vemos o nosso próprio equívoco de usuários de uma linguagem que nunca consegue esclarecer se é "meta" ou não. Podemos não perceber, mas rimos, ou sorrimos, de nós mesmos.

(Umberto Eco, 2006, p. 71)

\section{INTRODUCTION: THE EXPRESSIVE FORM OF MEANING}

The purpose of this article is to discuss the choice for footnotes during literary translation, as an endeavour to re-establish a connection between readers and the story through the references that are made - and which, otherwise, would possibly be lost. My notes themselves are not, however, an act of desperation; in my translation of Stephen Leacock's novel Sunshine sketches of a little town (1912), from English to Portuguese, they are but an attempt of bracing a dialogue already in motion. Therefore, as for the methodological organisation of this study to be unveiled, I shall first, within this introduction, reflect a little bit on the task of translation. Followingly, I bring two excerpts of the narrative selected wherefrom many hypertextual elements emerge, as for us to identify how, in just a few lines, many distinct meanings might be pullulating. These excerpts shall be broken into fragments and scrutinised in terms of the references that surface from the text, which are, on their turn, explained and discussed throughout the development of this article. The chief goal for such approach is thus to analyse the intertextual triggers manifested in the novel, bearing in mind that they often (and consciously) bring together fictional and nonfictional characters, historical events and imagination, existing places and fantastic ones. My hypothesis is that such strategy employed by Leacock (1912) transforms reality into a mystery and, thereby, confuse our very perception on the purported reality of facts.

Language can never be separated from the cultural elements that are in an endless dialogue with it - so that, through time, what a text "says" is never lost, but hijacked and released anew; if a language changes, its meanings also do: translation is a matter of transformation, not of defeat.One, therefore, can no longer ignore the fact that "because all human speech consists of arbitrarily selected but intensely conventionalized signals, meaning can never be wholly separated from expressive 
REVISTA X, Curitiba, volume 14, n.6,p. 203-217 2019.

form" (STEINER, 1975, p. 239). Both insides and outsides of words are in an intense interaction with one another, hence the impossibility for meaning to be wholly separated from its expressive form. The conventionalised signals can never be taken from one culture into another if not through a likewise intensive meaning metamorphosis; voluntarily or not, such process is inevitable, and not a hindrance to translate. This is why, assumingly or not, translation can only occur through creative infidelity: because there is no word that can be replaced by another as if the substitution of its cover could keep the core intact.

Changing words also means, inevitably, changing meanings. This is true not only for the tricky references I have just exposed, but, actually, for any other apparently less challenging term. "Even the most purely ostensive, apparently neutral terms are embedded in linguistic particularity, in an intricate mould of cultural-historical habit. There are no surfaces of absolute transparency" (STEINER, 1975, p. 240). As every word has an identity, perfect equivalence does not exist. The references provided by the sketches' characters, and the affectionate characterisation of Mariposa as a mould of a particular cultural-historical habit are my starting point. Both evince that translation can operate not as to provide the text with a surface of absolute transparency, but, on the contrary, it has to do with giving a literary piece one more layer of mobile meanings. We live within these unavoidable systems of mobile meanings; and translation might give us the tools to become less colour blind towards the specificity of the other. I want my readers to see in Mariposa, this ever-changing but never-dying town where Leacock's (1912) novel is set, other stories emerging, with new characters who are born through its recreation. The relevance of the town is indubitable, as one could say it actually stands for the main character of the narrative, whose plot concerns short sketches developing on the lives of those inhabiting Mariposa, usually between the paradox of rural and urban life, gazing nostalgically towards their small town and ambitiously towards the city.

The plot of Leacock's Sunshine sketches of a little town (1912), in a nutshell, consists in an array of distinct short narratives that are nonetheless in deep dialogue with one another. It provides readers with a humorous depiction of a small town in Canada that is, at that moment, going through a transformation: the gradual abandonment of British and French values and consequent rapport with U.S.A. culture. Characters are seen under the light of such historical context, and issues such as 
REVISTA X, Curitiba, volume 14, n.6,p. 203-217 2019.

colonisation, war, and the interaction of a panoply of identities that are now set alongside one another within the Canadian context are all put in the spotlight. There are stories about romance, about survival, rebirth, and, mainly, about nostalgia - as the first chapter is an eulogy to Mariposa and the last one a farewell devoted to the town that no longer exists.

The reader is able to see, in Mariposa, a micro-cosmos of all space and time: a contextual polymorphism. Mariposa can be thought in parallel with a past that recurrently assaults the present, providing new material for a given moment to be gazed upon through a more panoptic lens. This notwithstanding its supposed lack of importance when compared with regions with more metropolitan weight, and regardless of the limit status of the interferences it suffered from globalising relationships among spaces. The same argument is once again valid for translating Mariposa and reinserting it into a considerably distinct context; a process which allows the spatial and temporal channels of communication opened in the original text to be heightened, as "other pasts" are being allowed to dialogue with "other presents", in brand-new spaces. The straight temporal and spatial line is again transformed into a heterogeneous spiral. What is translation if not a chance for this time and space to be bridged? It is the very procedure that makes us talk to the other who is or has been, bringing the other closer or into the self, altering its status, modelling its nature. Learning with the other is, in the end, analogous with the learning of the self. The past is the threshold to the future, and literary translation (as a reconstruction of the past) gives us the tools to access new temporalities and spatialities for us to rebuild our own conceptions of our world - which is just one amongst many.

\section{DISCUSSION: "RELICS AND TRACES OF THE PAST"}

My analysis herein shall be limited to two specific moments of the novel, wherefrom several references surface during the descriptions of the narrator. Translating the story into Brazilian Portuguese, I have opted to provide my version with translation notes to unveil the implicit reasons behind such references - as many of them concern issues that would probably be more common to the "original reader" (the early 20th century Canadian) than to the one in my target context (the contemporary Brazilian). My strategy, however, is not unanimous to literary translators - as a matter of fact, it is far from being so, for, to many of them, I am eliciting issues that the author has him/herself chosen to leave implicit, besides adding information that is, according to 
REVISTA X, Curitiba, volume 14, n.6,p. 203-217 2019.

them, probably irrelevant to the story. However, pivotal or not for the plot to develop, the sketches' hypertextuality is rich for my readers to establish connections (not the same of the original, but brand-new, original, perceptions towards the story). That sort of hypertext can be observed in several moments of the narrative, but one that draws readers' attention is perhaps when two characters, Dr. Gallagher and Dean Drone, are on the ship Mariposa Belle (before it sinks), gazing upon the landscape and sharing insights about it. Within such reasoning past and present are intermingled in a confusing, but rather informative, fashion, and the chronotope of the sketches is ultimately expanded. In the following excerpt, we are given a lot of evidence on this nonlinear articulation. This evinces that digressions occur regarding not only inthe narrator's discourse, but also in what goes to the discourse and conversations of those s/he describes.

Dr. Gallagher said that it was just here that a party of five hundred French had made their way with all their baggage and accoutrements across the rocks of the divide and down to the Great Bay. And Dean Drone said that it reminded him of Xenophon leading his ten thousand Greeks over the hill passes of Armenia down to the sea. Dr. Gallagher said that he had often wished he could have seen and spoken to Champlain, and Dean Drone said how much he regretted to have never known Xenophon. And then after that they fell to talking of relics and traces of the past, and Dr. Gallagher said that if Dean Drone would come round to his house some night he would show him some Indian arrow heads that he had dug up in his garden. And Dean Drone said that if Dr. Gallagher would come round to the rectory any afternoon he would show him a map of Xerxes' invasion of Greece. Only he must come some time between the Infant Class and the Mothers' Auxiliary. (LEACOCK, 1912, p. 50)

Here we have two rather distinct historical moments, but whose relevance seems evident and akin to one another, at least for the characters who compare them. One of the rocky landscapes the boat goes through allows Dr. Gallagher to reconstruct the image of a party of five hundred French walking with their baggage and accoutrements

\footnotetext{
${ }^{2} \mathrm{O}$ Dr. Gallagher disse que havia sido exatamente por aqui que um grupo de quinhentos franceses tinha passado com todas suas trouxas e apetrechos descendo por entre as rochas da divisão até o Great Bay. E foi o reverendo Drone quem disse que a estória o fazia lembrar-se de Xenofonte conduzindo seus dez mil gregos ao longo das colinas da Armênia até chegar ao oceano. Dr. Gallagher contava que já havia frequentemente desejado ter tido alguma oportunidade de conversar com Champlain, e o reverendo, por outro lado, se lamentava por nunca ter conhecido Xenofonte. Após começarem a refletir sobre relíquias e traços do passado Dr. Gallagher comentou que, caso o reverendo Drone pudesse vir a sua casa qualquer tarde dessas, ele podia mostrar algumas das pontas de flechas indígenas que havia desenterrado do jardim. E assim Drone respondia que se o Dr. Gallagher pudesse vir a sua paróquia qualquer tarde dessas ele poderia mostrar um mapa da invasão de Xerxes na Grécia. Ele apenas alertou que, caso o Dr. Gallagher pudesse fazê-lo, que viesse entre a classe infantil e o acompanhamento familiar. (Every translation of Leacock's novel into Portuguese, presented in this paper, is mine.)
} 
REVISTA X, Curitiba, volume 14, n.6,p. 203-217 2019.

until they reached the Great Bay. Such journey, on the other hand, gave Dean Drone the possibility to go beyond Gallagher's imagistic construction when he says the very same landscape reminded him of Xenophon walking with his group until they reached not the Great Bay but the sea.One recollects moments of historical relevance to America, and the other recollects moments of Ancient History - both likewise essential for one's understanding of what has lead him/her to the present, confusing temporal and spatial linearity. The comparison is an extended one, and such characters demonstrate how they would like to get closer to a time and space they respect, but is unfortunately no longer available. The end of the paragraph is evidence that the different images they construct out from the landscape they are both going through are not a reason for conflict, but of mutual learning. Interestingly enough, they are both going through the same space at the same time, but their distinct identity, personality, and background knowledge, the systems of meaning surrounding their existence, gives them the opportunity to shape completely deviant (but never opposing) versions of analogies.

These are references concerning the metaphoric nature of such landscape, out of which the narrator, on the other hand, is unable to build any image at all. Both characters seem interested in elaborating on their insights during the moment when they watch the landscape through different lenses. If, for Dr. Gallagher, the Indian arrow heads are reminders of a history that may be resurrected for a posthumous reflection, Drone is sure that a map of Xerxes' invasion is also still capable of giving one the opportunityto resurrect a much older and distant history. As mentioned, in my reading, these hypertextual references are certainly worth looking at. In this excerpt the reader gets in touch with aspects of Canadian past, through the comments put forward by Dr. Gallagher, and with the ones concerning Ancient history, through the comments put forward by Dean Drone. The first reference, which regards Canadian history, is to the setting of much that has happened in its colonial past: The Great Bay. The Great Bay is a natural landscape that has shaped the history and culture of North America. Very rich in natural resources, the region was the reason of several battles between Native Americans and European settlers during colonial processes, and would, after 1623, become an important fishing area for the early British and French colonies.

That space configured nonetheless not only the reason for the conflict between settlers and natives, but also between settlers themselves with one another, for it provided an advantageous perspective since the waterways of the estuary also provided 
REVISTA X, Curitiba, volume 14, n.6,p. 203-217 2019.

access to settlements on the tributaries and the Native American tribes. It seems thus to be avery stunning landscape indeed, but also one marked by a conflictive situation, especially after the war that attacked both sides of the river, killing or capturing nearly one hundred settlers and burning half of the settlement to the ground. "While the attack devastated the small colony, peace was eventually restored and settlers returned to the area" (TAYAC, 2006, p. 21). Because of the mentioned rich natural resources of the Great Bay, the area went through a severe environmental threat during the period when Leacock's novel was written. But, fortunately, especially after 1973 - about 60 years after Sunshine Sketches was published - projects for its preservation were devised and applied, and today the region is safe and finally enjoyed for the recreation, education, and research opportunities it offers - evading the sad destiny to which former explores had been leading it. The following reference is now to Samuel Champlain, deemed by many Canadians the father of new France. Champlain was a Norwegian explorer who was born somewhere circa 1572 and died in1635; said to have founded the Canadian city of Quebec, he helped to colonise the whole French North America.

As an explorer, he is considered the forerunner in what regards radar navigation since the system had been invented less than 30 years before when he decided to use it which has made him one of the first explorers to actually navigate guided solely by radar. Sent by the king Henry IV of France, Champlain got to Canada and, especially, to the Niagara Falls for the first time in 1603; after some journeys throughout the region he would finally settle down in the town he decided to name Quebec (which would become the first permanent settlement in New France). Different from many other settlers, historical evidence brings surprising data concerning Champlain's initial relationship with local natives who, it seems, ended up befriending him during his settling in the region. Such friendship would prove to be useful when those natives, becoming allies of the settlers (Algonquin and Huron ones), helped the European invaders fight against the Iroquois Indians who were, at the moment, in the region where New York isnow located. His greatest conquest is considered by many historians to be the Lake Champlain - the largest body of water totally in colonisers' control up to that moment. Ultimately he would be taken to Europe as a prisoner after Anglophone colonisers captured Quebec and, when it was once again in Francophone hands, he would return to the region to try rebuilding what he had built before his involuntary withdrawal. Finally, concerning Ancient History, the reference is to the king of Persia, Xerxes the Great, also 
REVISTA X, Curitiba, volume 14, n.6,p. 203-217 2019.

known as Xerxes I of Persia, King of Babylon, King of Media, Great King, King of Nations, and/or King of Kings.

Having lived from 519 until 465 BC, Xerxes, the fourth king of Persia, succeeded his father at the age of 36 years old, surprisingly, for that time, without any enemies to challenge his crowning. He was actually the one who created such title, since he despised the one he was likely to have (The King of Babylon) due to his lack of esteem for the people that would accompany his status, famous for keeping up to Darius's plans to prepare an army to invade Greek mainland. "History says that this was the man responsible for digging a channel capable of allowing: Assyrians, Babylonians, Egyptians, Jews, and Phoenicians go through in their way to fight Athenians, Eretians, and Naxians" (OLMSTEAD, 1966, p. 368). This "necessary" conflict was devised probably due to the traditional feud between these peoples, which had emerged and evolved since the Ionian Revolt. The greatest revolts dated during the period when Xerxes led Persian people were the ones taking place in Babylon and Egypt. Incidentally, a curiosity about him is the fact that he was the first king to effectively consider himself a Zoroastrian - that is, one of those sharing the former religious belief of the ancient Persian Empire, whose Manichean construction of good/evil and hell/heaven is currently taken as one of the main sources for Modern Christianity. "Spenta Mainyu, Progressive Mentality, represent the positive realms of the dogma; and Angra Mainy, Destructive Mentality, the negative ones: both traditional versions of what Christianity separates as that which belongs to the Devil and that which belongs to God" (OLMSTEAD, 1966, p. 201).As a matter of fact, the king's religion (Zoroastrianism) has not only provided the basis for Christianity, but also for all Gnosticism, Judaism, and, ultimately, Islam - as all have this main framework in common.

Ergo, dissecting the textual body of Leacock's Sunshine sketches of a little town (1912) helps me re-textualise it, highlighting and enhancing its cultural potential, for me to eventually rebuild the relationship not only between reader and characters, but even concerning characters themselves. That is: the idea of looking at the story hypertextually - attentive to all the hidden references it makes - gives me room to observe other relations, to see connections that are also amenable to be reconfigured through translation. In the end, the point of translation is raising awareness that we are dealing not with a single text, but with many distinct texts entangled within a specific narrative. 
REVISTA X, Curitiba, volume 14, n.6,p. 203-217 2019.

With that in mind, another key moment of the novel that provides one more stone to build the bridge between source and target contexts takes place when the narrator observes (and seems to be one of the few characters to understand) the particular manner whereby Mr. Pupkin courts judge Pepperleigh's daughter Zena, many pages before they are finally engaged.

The people on Oneida Street thought that Mr. Pupkin was crazy, but Zena Pepperleigh knew that he was not. Already, you see, there was a sort of dim parallel between the passing of the bicycle and the last ride of Tancred the Inconsolable along the banks of the Danube. Zena gave one look of appeal to Pupkin, and Pupkin looked one glance of comprehension, and turned and fled down Oneida Street. And if the scene wasn't quite as dramatic as the renunciation of Tancred the Troubadour, it at least had something of the same elements in it. Pupkin walked home to his supper at the Mariposa House on air, and that evening there was a gentle distance in his manner towards Sadie, the dining-room girl, that I suppose no bank clerk in Mariposa ever showed before. It was like Sir Galahad talking with the tire-women of Queen Guinevere and receiving huckleberry pie at their hands. (LEACOCK, 1912, p. 102) ${ }^{3}$

Even though most people in Mariposa believe Mr. Pupkin, the bank clerk, is not perfectly compos mentis when he decides to ride his bicycle along the street repetitively and without any major purpose, the narrator knows there is something honourable triggering his resolute pursuit. Hence the farfetched comparison between the passing of Pupkin's bicycle and the last ride of Tancred the Inconsolable, as the narrator again overstates events going on in Mariposa, discursively enhancing their importance. Pupkin's running away from the character Zena the moment she decides to look back at him, reminds the narrator of the same elements concerning the atmosphere of Tancred's renunciation. Even though sometimes it seems the narrator deflates fairy tales as to privilege Canadian historical facts, such as when s/he criticises the books Zena enjoys, mostly what we have is this sort of intermingling of history and fantasy, myth and

\footnotetext{
${ }^{3}$ As pessoas na Oneida Street rotularam o Sr. Pupkin como louco, mas Zena Pepperleigh sabia que louco ele não era. Já nesse momento, percebes, havia algum tipo de leve paralelo entre a passagem da bicicleta e o último passeio de Tancred the Inconsolable ao longo das margens do Danúbio. Zena deu um olhada de apelo a Pupkin que, por outro lado, parecia responder com um olhar de compreensão, antes de virar-se e descer em fuga à Oneida Street. E, como se tal cena já não fosse tão dramática quanto aquela da renúncia de Tancred the Troubadour, ela continha pelo menos alguns de seus mesmos elementos. Pupkin voltou para jantar ao ar livre na Mariposa House, e, naquela noite, havia como que uma suave distância em seu comportamento para com Sadie, a garota responsável por servir-lhe na sala de jantar. Ainda não consigo imaginar nenhum outro bancário de Mariposa demonstrando atitude parecida. Aquela imagem me parecia equivalente a algo como o Sir Galahad conversando com as criadas particulares da rainha Guinevere e recebendo torta de mirtilo de suas próprias mãos.
} 
REVISTA X, Curitiba, volume 14, n.6,p. 203-217 2019.

reality, the real Mariposa and the imaginative one (and this is one of such cases). Moreover, alleging that probably no bank clerk in Mariposa is as considerate as this gentleman (especially when he handles people in a lower rank), the narrator is sharing images that give Pupkin this semblance of knightliness.

His manners with Sadie, the dinning-room girl, reminds the narrator of Sir Galahad and the tire-women of Queen Guinevere - another exaggerated image, but coherent with the previous associations. Here, it is not only the information itself that is really that remarkable, but the narrator's ability to go back and forth in time and space (historical and mythical) when coming up with such inferences. As if s/he had no reason to temporally organise what s/he is saying, for him/her past and present, as well as myth and truth, are generally amalgamated. Therefore, understanding the analogy made by the narrator between Mr. Pupkin and Tancred requires us to go a little bit further into the hypertextual relevance of the latter. The "real person", if I can put it that way, to whom we associate the name Tancred is a Norman leader of the first crusade, born in 1075 and deceased in 1112:

\begin{abstract}
After the war, Tancred would become the Prince of Galilee - title with which he was bestowed after he had established the Kingdom of Jerusalem - being rather illustrious at his time, well-known as the first crusader to enter Jerusalem, even though it was Ludolf of Tournai who first entered the city. (KELLEHER, 2013, p. 25)
\end{abstract}

However, it does not seem that this is the man towards which the analogies put forth by Sunshine sketches' narrator are directed. The images that s/he is able to come up with when observing Mr. Pupkin courting Zena are, more likely, due to a correlation between this scene and the novel Tancred (DISRAELI, 1847). The protagonists of the story are the couple Tancred the Troubadour and Maria Partecipazio. Since they belong to distinct social ranks, reason why society disapprove their union, these characters could only interact through the exchange of looks and smiles when they walked past each other on the streets. Their fear to be judged by those surrounding them is, to the narrator, probably synonymic to the fear that prevents Mr. Pupkin from behaving differently in what concerns his admiration towards Zena. Such reading is possible, inasmuch as readers are recurrently reminded of how normativity has never abandoned Mariposa, especially in regards to marriage.

It does not matter how the surrounding atmosphere might be different; to the narrator it is their feelings that allow such parallel to be drawn. After failing in most of 
REVISTA X, Curitiba, volume 14, n.6,p. 203-217 2019.

his plans, Tancred sees in going to war a possibility for him to improve his social status and envisage a possibility to ask Maria's hand in marriage. He ends up rather tragically killed in a Hollywoodian scene: wounded in battle, Tancred falls over white roses that are gradually tainted by his blood until they become completely red. Curiously, Benjamin Disraeli, like Leacock, was also a British born writer of political, social, and fictional pieces. He had Jewish origins and was born in 1804 and died in 1881, having served two times as the Prime Minister of Britain during the period. Even though Leacock never seemed to have considered himself a true liberal or conservative, this, who was the creator of the conservative party of England, was a man he credited and admired considerably - perhaps another reason why the reference is made.

A curiosity about the character of this key figure for the constitution of the conservative party is his hybrid upbringing between Jewish and British tradition; his religious orientation, for instance was divided between Judaism and Anglicanism. After becoming an Anglican, Disraeli and Queen Victoria established a rather close friendship, an aspect that allowed him to become even more involved in Britain's international affairs - especially in those concerning its relationship with Russia. (BLAMIRES, 2003, p. 112)

By the middle of his concrete career as a politician, Disraeli started writing novels idly, which he kept doing even after this career was finished, until his death. It is within this context that Tancred is written, not devoid of its own contextual references to the condition wherein Disraeli found himself then. Given that Tancred is an artist and Maria a noblewoman, the financial and social distinctions between them are not difficult to be inferred. Similar to other stories following the same reasoning, such distinctions are what seem to boost the romantic atmosphere around them and to motivate courage and bravery to help them surpass obstacles in the name of love. Both characters, while looking for manners to put their plans into practice, end up forsaking control and allowing their impulses to act - which generally results in their making a huge mistake: the hubris (which generally causes the characters' death and thus result in the readers' convincement that the final impracticality of their love can no longer be dodged). "This is Disraeli's most well-known novel, and, to many critics, probably stands to the greatest inner and outer conflict Disraeli himself had lived: that of Christianity versus Judaism" (BLAMIRES, 2003, p. 113). It seems rather probable then, and by the same token, that Leacock is referencing this story; but the last analogy of the excerpt analysed is perhaps even clearer. This one takes place when the narrator poses that Mr. Pupkin 
REVISTA X, Curitiba, volume 14, n.6,p. 203-217 2019.

talked with his maid as if he were talking with the tire-women of Queen Guinevere as to demonstrate how gentle this character is.

Now, then, the narrator is moving from historical figures onto the grounds of fictional ones - which evince the intricate intertextual attributes of Leacock's (1912) narrative. Queen Guinevere, like Sir Galahad, is a character of considerable importance, now for the Arthurian legend - which is something Leacock seemed to appreciate somewhat significantly, given the recurrence of members of the legend. Her appearances also take place in Lancelot Grail Cycle (1210-1230), Post-Vulgate Cycle (1230-1240), and at Le Morte d'Arthur (1485) - perhaps the very three books about the legend that Leacock had access to, since both Guinevere and Galahad (who emerge in such tales) are referred to in the sketches. "Guinevere was the legendary Queen consort of King Arthur. In tales and folklore, she was said to have had a love affair with Arthur's chief knight Sir Lancelot"(BRIDGWOOD, 2011, p. 484).Love is to be the emotion that can most summarise the feelings coming from and to such subject, whose participation in the legend is divided between dreadfulness and remission concerning her relationship with important male characters of the round table. Eventually, in fact, Guinevere and Lancelot's betrayal of Arthur was often considered as having led to the downfall of the kingdom, which turns her into one of the major triggers for Lancelot and Arthur's feud to be born and nourished during the tales. Having descended from a noble family of Romans, Guinevere is the daughter of Leodegrance, previous owner of the Round Table, which she brings, together with one hundred knights, as her dowry when she marries Arthur.

She is most well-known in the legend as the charlatan accomplice to Mordred's treachery against Arthur and due to her lifelong relationship with Lancelot, who rescues her from being burnt at the stake for adultery, and eventually brings about the downfall of Camelot. In a nutshell, the books extensively describe Arthur's feelings towards Guinevere, but hers are never disclosed - until her final betrayal occurs. When her plan is discovered it is far too late; Arthur had already been blinded: At that point Merlin warns Arthur that Guinevere is not wholesome enough to be his wife, and that Lancelot would love her (and she him). But Arthur's heart is set. Throughout the three books I mentioned previously in this paragraph readers are told the tale describing Guinevere being abducted; in fact, "Guinevere's abduction by men is a recurring theme throughout 
REVISTA X, Curitiba, volume 14, n.6,p. 203-217 2019.

Arthurian legend, and when kidnapped, she must be saved - the epitome of the damsel in distress, though never is she at serious risk of harm" (BRIDGWOOD, 2011, p. 485).

Like in the case of the character Zena, if Guinevere's life is tragic, she also represents an ideal - that of courtly romance. Obviously too, she remains both desirable and well-protected (sometimes too well), and avoids execution at the stake several times. The dualism here is no longer between religious issues, but between moral corruption and integrity: "In the end, Guinevere's enduring love of her equally devoted Lancelot, and the resultant betrayal of King Arthur, brought about the end of the Round Table and the fall of Camelot; but she was a true lover and therefore had a good core"(MALORY, 2015, p. 54). Her remission, therefore, does not have to do with her actions or with what she feels, but with the real, honest, and candid feelings she is capable to cause in other characters. The interest of Mr. Pupkin in Zena is made clear through the images provided by the narrator (images that, ironically, put subjects we know nothing about in parallel with figures of canonical importance). Zena's interests, on the other hand, are never that clear; perhaps because, as a woman, they were still not as important - in early $20^{\text {th }}$ century Canada or to the Arthurian legend.

\section{FINAL REMARKS: “AS IMPOSSIBLE AS POSSIBLE”}

Providing this extra information concerning contextual references that, like the ones just analysed, are intermingled within the narrative is in my view important not only for giving the reader an opportunity to enhance their awareness towards Stephen Leacock's (1912) possible paths for coming up to these parallels, but also to make them capable of grasping the level of exaggeration present in many of their usages. That is: without making out what sort of parallel is being established, my interlocutor would not be able to understand how farfetched it actually proves to be. The process of comparing these local characters, completely unknown to the reader prior to their characterisation in the novel, to historical and fictional figures that are part of an established cultural system might be read as part of the narrator's attempt to demonstrate how things are repeated over and over, throughout the passage of time. S/he is reminding us of how the choices, paths, and destinies of some are nothing but a retextualisation of those narratives that have already been practised somewhere else. Now, the fact that we are dealing here with a humorous piece with a clear inter and hyper-textual agenda (resulting in considerable anachronisms that demand a lot of thinking to be undertaken by the reader)brings irony as perhaps one of greatest tools for this temporal conduit 
REVISTA X, Curitiba, volume 14, n.6,p. 203-217 2019.

between past, present, and future to be conceived - especially through the references analysed

The idea that the translator should worry about bringing extra information in the form of notes and/or glossaries to readers only when they prove to be unquestionably essential for the narrative to move on smoothly seems to be the argument of many translation scholars, and often not to use them. I have to disagree - as theorists such as Schleiermacher (2001) and/or Venuti (1998) have also done. To my understanding, everything in a literary piece is significant, regardless of its given function in this or that moment; and, thus, every chosen word shall be looked at with care, given its cultural potential. It does not matter what seems to be relevant for the development of the plot, sometimes a narrative has many aspects that go beyond its chronotope, pointing to other directions. That is, there is no way to say what is and what is not important in a narrative for that changes given temporal, spatial, and actually personality traits. The role of a translation, in this sense, is not to limit one interpretation due to its insertion in a certain context in a given time, but to expand meanings without imposing new borders around them. Therefore, if such line of reasoning is followed, it would be fair to say Brazilian readers would inevitably benefit from being aware of the historical and cultural contextual links established by the novel's narrator, and that is what my paratexts aim at providing.

Such interpretive expansion is also crucial for the effective maintenance of the narrator's irony, whose attributes have predesigned the features of the original characters at the very same time that they are providing me with the raw material to coming up with a brand new characterisation for them. This inasmuch as "it is this irony which literature is ideally equipped to act out in the lives of its characters, who spring forth, with the mark of destiny on their brows, and in so doing rouse the goddess fortune to oblige them by making the destiny as impossible as possible" (ROURKE, 1959, p. 235). Acting out in the lives of characters, the ironic aspects of our narrator's comments fuse the lives of those who have been and those who are, ultimately inserting the mark of destiny on their brows. Bearing in mind that such destiny is turned by irony into something as impossible as possible, this artefact is not directed into a deterministic characterisation at all; it is just offered as a mechanism for the reader to take the past out of the invisible box where it had been cornered and bring it back to the game. Like Leacock's narrator, translation operates as to make us, through the usage of a present 
REVISTA X, Curitiba, volume 14, n.6,p. 203-217 2019.

object, be transported to spaces and times that, at a first moment, did not seem to have any relevance for the material existence of that object. It is, like literature, a channel to the unseen, a lens for us to see the invisible, to experience what is apparently not amenable to experience. Translating is realising that the past has not left us, and that in fact it never will.

\section{REFERENCES}

BRIDGWOOD, R. “The Depiction of Lancelot in Chrétien de Troyes'The Knight of the Cart and Malory's 'Book of Sir Lancelot and Queen Guinevere' in LeMorte Darthur," Innervate. Nottingham, v. 3, n. 1, p. 480-487, 2011.

ECO, U. Entre a Mentira e a ironia. Trans. Eliana Aguiar. São Paulo: Record, 2006.

DISRAELI, B. Tancred. UK: Kessinger Publishing, 1847.

KELLEHER, R. Kings in Medieval England. Cambridge. Fitzwilliam Museum Press, 2013.

LEACOCK, S. Sunshine sketches of a little town. Toronto: Bell \& Cockburn, 1912.

MALORY, T. Le Morte d'Arthur. New York: Collectible Classics, 2015.

OLMSTEAD, A. History of the Persian Empire. Chicago: University of Chicago Press, 1966.

SCHLEIERMACHER, F. "Sobre os diferentes métodos de tradução." Clássicos da teoria da tradução: Edição bilíngue (Volume I-Alemão/Português). Ed. Werner Heidermann. Trans. Margarethe von Mühlen. Florianópolis: Núcleo de Tradução, 2001.

ROURKE, C. American humour. San Diego: Harcourt Brace Jovanovich, 1959.

STEINER, G. "The claims of theory." After babel: Aspects of language and translation. London: Oxford University Press, 1975. 236-295

TAYAC, G. We have a story to tell: Native peoples of the American region. Washington: National Museum of the American Indian, 2006.

VENUTI, L. Scandals of translation: Towards an ethics of difference. London: Penguin, 1998. 